\title{
Monoclonal Antibody B6.2F(ab')2
}

National Cancer Institute

\section{Source}

National Cancer Institute. Monoclonal Antibody B6.2F(ab')2. NCI Thesaurus. Code C29209.

A divalent $F(a b) 2$ fragment of the monoclonal antibody (MoAb) B6.2 directed against the tumor-associated glycoprotein (TAG-90) found on the surface of primary and metastatic human mammary tumors.. MoAb B6.2 F(ab)2 fragments are obtained through pepsin digestion. The advantage of using MoAb B6.2 F(ab)2 fragments over whole antibodies is that they have reduced immunogenicity, better penetration of tissues, rapid clearance from the body and that they do not induce precipitation. 